\title{
Die verhouding tradisie-redaksie in gelykenisinterpretasie
}

GMM Pelser

\begin{abstract}
The interrelationship between tradition and redaction in parable interpretation
\end{abstract}

This paper investigates the legitimacy and possibility of isolating the parables from their holistic literary gospel-context for the purpose of hearing and understanding them from other possible angles. The conclusion reached is that the parables as aesthetic objects (Via) have a certain independence and that they contend with the gospels for the focal attention of the reader. As metaphors they are generative of multiple meanings and their 'meaning' cannot be one-sidedly forclosed in their present literary context or in some historical moment. When the parables are read as part and parcel of the gospels as literary macro-Gestalten this holistic context, however, should not be ignored.

\section{KORT HISTORIESE OORSIG VAN DIE GESKIEDENIS VAN GELYKENISINTERPRETASIE}

\subsection{Jülicher}

'Adolf Jülichers Gleichnisanalyse aus den Jahren 1886 und 1899 wird von der ntl Forschung allgemein als die Grundlegung der modernen Gleichnisforschung anerkannt' (Güttgemanns 1971a: 104).

Hierdie opmerking gee uitdrukking aan 'n nuwe wending wat daar aan die einde van die negentiende begin twintigste eeu in gelykenisnavorsing ingetree het en wat van so ' $n$ aard was dat ' $n$ mens dit as ' $n$ waterskeiding kan tipeer. Die geskiedenis van gelykenisinterpretasie kan hiervolgens met reg verdeel word in die periodes 'voor en na Jülicher' (kyk Kissinger 1979: 72). Vir Jülicher se werk aan die gelykenisse het as spoorslag gedien sy misnoeë met die willekeurige allegoriese interpretasies waaraan die gelykenisse reeds deur die evangeliste en deur die eeue heen onderwerp is. Hy het dit daarom as sy belangrikste taak gesien om die gelykenisse hiervan te bevry en aan hulle *Referaat gelewer voor die Hervormde Teologiese Vereniging op 26 Junie 1985. 
hulle oorspronklike plek en betekenis terug te gee. Vir hierdie doel het hy op die voetspoor van Aristoteles onderskei tussen vergelyking en metafoor: 'n vergelyking is 'eigentliche Rede' en so ook 'n gelykenis; 'n metafoor is 'uneigentliche Rede' en so ook 'n allegorie. 'n Allegorie is $v i r$ ingewydes, vir oningewydes is dit ' $n$ raaisel, terwyl ' $n$ gelykenis met die werklikheid te doen het, en in die Nuwe Testament met die werklikheid rondom die historiese Jesus. Jülicher was dus van oortuiging dat die gelykenisse alleen reg verstaan kon word as hulle in die konteks van die aardse Jesus en sy optrede geïnterpreteer sou word. Daar moes terugbeweeg word na die 'unverfälschte, historische Jesus'. Omdat hy egter die didaktiese karakter van die gelykenisse so sterk beklemtoon het, het hy uiteindelik die gelykenisse gesien as die verwoording van algemene (morele) waarhede. Ironies genoeg het hy hom juis as gevolg hiervan sterk kritiek deur sommige op die hals gehaal, omdat geoordeel is dat hy hiermee die historiese, Christologiese en eskatologiese karakter van die gelykenisse misken het (Weder 1978: 17; Jeremias 1962: 15; e a).

Jülicher het ook nog ander standpunte in verband met die gelykenisse gehuldig wat in die besinning na hom navolging gevind het en verder ontwikkel is. lets wat veral in die vormkritiese hantering van die gelykenisse aandag gekry het (bv by Bultmann 1967: 179 vv; Linnemann 1961: $13 \mathrm{vv}$ ) is die verskillende kategorieë van beeldspraak wat hy in die sinoptiese oorlewering onderskei het, te wete gelykenis, allegorie, fabel en voorbeeldvertelling (Beispielerzählung). Nog 'n opvatting wat deur hom gehuldig is en waarin hy deur sommige sterk nagevolg is (bv Dodd 1965; Jeremias 1962; Linnemann 1961) en deur ander gekritiseer is (bv Jüngel 1967; $95 \mathrm{vv}, 135 \mathrm{v}$; Via 1974: $2 \mathrm{v}$ ), is sy tese dat ' $n$ gelykenis in onderskeid met ' $n$ allegorie, bestaan uit ' $n$ beeld- en ' $n$ saakhelfte en slegs een punt van vergelyking (tertium comparationis) het. Omdat 'n gelykenis volgens Jülicher op 'n spesifieke situasie in Jesus se tyd betrekking gehad het en ' $n$ bepaalde didaktiese funksie moes vervul, wou dit slegs een punt by die hoorders tuisbring en het alle ander elemente in die gelykenis slegs na hierdie een punt heengewys.

\subsection{Na Jülicher - dominansie van historiese vraagstelling}

Die doel van hierdie studie is nie om in te gaan op alles wat Jülicher en ander na hom oor gelykenisinterpretasie te sê gehad het nie. Die doel is primêr om te vra na wat as legitieme konteks by die interpretasie van 
gelykenisse moet of mag geld. Die vraag is dus of daar geskei of onderskei mag word tussen tradisie en redaksie. Dit wil sê, mag 'n gelykenis ge-ontkontekstualiseer word deur dit te isoleer of los te maak van die makro-konteks van die evangelievertelling waarin dit opgeneem is en dan teen ' $n$ ander agtergrond geïnterpreteer word?

Gaan kyk 'n mens na die werk wat op dié van Jülicher gevolg het, dan merk jy op dat die aanvoorwerk wat hy gedoen het met betrekking tot die plasing en interpretasie van die gelykenisse teen die agtergrond van die situasies rondom die aardse Jesus, deur ander progressief verder gevoer is. Dit is verder gevoer deur mense soos AT Cadoux en BTD Smith (kyk Jeremias 1962: 17) en het 'n sekere hoogtepunt bereik met die werk van Dodd en Jeremias. Die wagwoord het nou geword: terug na die aardse Jesus om enersyds uit te kom by die ipsissima verba of vox lesu en om andersyds die gelykenisse te verstaan soos die oorspronklike hoorders dit moes verstaan het. Alleen in samehang met hulle oorspronklike historiese situasie laat hulle hulle oorspronklike betekenis bekend word. 'In ihrem Bezug auf ihre geschichtliche Ursprungssituation wollen sie erkannt werden, denn gerade so erweisen sie ihre Bedeutung, die über jene Situation weit hinausgeht' (Linnemann 1961: 41).

Min navorsers het so indringend en uitvoerig as Jeremias probeer vasstel wat die oorspronklike vorm van die gelykenisse was en watter lotgevalle hulle ervaar het in die mondelinge oorlewering van die vroegste kerk. Hy gaan daarvan uit dat die gelykenisse ' $n$ 'zweifachen historischen Ort' het, naamlik enersyds hulle oorspronklike historiese plek en andersyds die geskiedenis wat hulle deurgemaak het toe hulle in die vroegste kerk 'geleef' het voordat hulle skriftelik gefikseer geraak het. Dit is gedurende hierdie periode toe hulle in die vroegste kerk geleef het, dat hulle onderwerp is aan verskeie wyses van omvorming wat elkeen op sy beurt aan hulle oorspronklike betekenis verander het. Jeremias lys 'n twaalftal 'Umformungsgesetzen' waaronder omvormings deur vertaling in Grieks, verandering van dekor, verandering van aangesprokenes, toepassing op die situasie van die kerk, paranetiese aanwending, allegorisering, ensovoorts (1962: 21-23).

Dat die tradisie-eenhede wat ons in die Nuwe Testament en veral in die Sinoptiese Evangelies aantref, gedurende die mondelinge oorlewering daarvan allerlei omvormings deurgemaak het vanweë verskeie faktore wat op hulle ingewerk het, is nie te betwyfel nie. ' $n$ Mens kan daarom tot op groot hoogte met Jeremias saamstem oor wat hy vermoed daar alles met die gelykenisse gebeur het. 'n Mens sien trouens 
nog duidelike tekens daarvan in die wyse waarop die verskillende evangeliste hierdie materiaal hanteer het om hulle eie teologiese perspektiewe by hulle lesers tuis te bring. Om sodanige 'omvormings' in die vroegste tradisie as ' $n$ feit te aanvaar, is egter een saak, om ' $n$ geldige kriteria te vind waarvolgens dit vasgestel kan word, is ' $n$ ander.

Nogtans is daar aan die hand van bepaalde kriteria, hoofsaaklik dié van nie-ooreenstemming, samehang en meervoudige betuiging ( $\mathrm{kyk}$ Perrin 1967: 15-17; Jeremias 1973: 13-15), maar ook deur middel van vorm- en redaksiekritiek, dikwels gepoog om die ontstaan en geskiedenis van die tradisie-eenhede na te speur. Dit is opvallend dat die meerderheid gelykenisnavorsers sedert Jülicher op een of ander wyse probeer terugvra het na die oorspronklike vorm van die gelykenisse asook na die situasie in die lewe en werk van die aardse Jesus waarop hulle betrekking sou gehad het. Benewens die reeds genoemde werk van Cadoux, Smith, Bultmann, Dodd, Jeremias en Linnemann kan in hierdie verband ook nog verwys word na die werk van Jüngel (1967), Fuchs (1970), Wilder (1971), Crossan (1973), Weder (1978), Stein (1981), Snodgras (1983), Boucher (1981) en in 'n mindere mate Funk (1966).

In hierdie ondersoeke was die motief egter nie bloot om by die historiese Jesus en die outentisiteit van die gelykenisse uit te kom nie, maar beslis ook die strewe om die gelykenisse te verstaan soos hulle oorspronklik bedoel sou gewees het om verstaan te word. Dat daar beslis insiggewende resultate deur middel van die historiese vraagstelling verkry is, kan nie ontken word nie. Of daarin geslaag is, of in alle gevalle daarin geslaag is om ons by die ipsissima verba of vox Jesu uit te bring, sal egter altyd 'n debatteerbare saak bly en sal ons waarskynlik nooit weet nie.

\section{KRITIEK OP HISTORIESE VRAAGSTELLING}

$\mathrm{Al}$ sou ons egter ook tot op sekere hoogte die juistheid van die resultate van die historiese of vormkritiese vraagstelling kon aanvaar, beantwoord dit nog nie die vraag na die prinsipiële of metodologiese legitimiteit van hierdie vraagstelling nie. Solank die vormkritiek as aanvaarbare eksegetiese metode beskou is, was daar natuurlik geen beswaar nie. Die opkoms van die redaksiekritiek, die strukturalisme en die 'nuwere' literêre teorieë het egter die saak baie problematies gemaak. Hierdie benaderinge gaan, soos bekend, almal in mindere of meerdere mate daarvan uit dat elke teks 'n outonome skepping is wat in terme van sy eie poëtiek en koherensie gelees en geïnterpreteer moet word. In so 'n makro-teks word betekenis sinkronies en binne die raamwerk 
van die makro-struktuur gegenereer en mag dit nie van buite af in die teks ingedra word nie. Die evangelies word ook as sodanig beskou, selfs al is dit so dat hulle outeurs van tradisiemateriaal gebruik gemaak het. Hulle is dus nie blote sameflansings van kleiner eenhede nie, maar elkeen 'n koherente vertelling met 'n eie plotontwikkeling en ideologiese (teologiese) perspektief (vgl Van Aarde [1983]: 58-60). Die evangelies word dan ook gesien as nuwe skeppinge en nie as eindstadiums van die voorafgaande mondelinge tradisie nie.

In die lig hiervan word daar beswaar gemaak teen die diakroniese, genetiese hantering van evangeliemateriaal deur die vormkritiek. Die vormkritiek word daarvan beskuldig dat hy nie na die evangelies as outonome tekste kyk nie, maar deur hulle kyk en agter hulle gaan vra na die ontstaan van die tradisie-eenhede en hulle evolusionistiese ontwikkeling tot die evangelies wat ons vandag voor ons het (kyk Güttgemanns 1971b; Van Aarde 1982: 13-15; Vorster 1982: 103-104; Sider 1983). Die volgende stelling van Güttgemanns met betrekking tot die plek en funksie van die tradisie-eenhede in hulle nuwe konteks, kan as verteenwoordigend beskou word van hierdie holistiese benadering tot tekste.

'Die Form des Evangeliums ist eine sprachliche "Gestalt" eine unlösbare dialektische Einheit von traditionsgeschichtlich überkommenem "Material" und intentional-akthafter Gestaltung der Sprachlichen "Form", die das "Material" "aufhebt" indem sie es als Darstellungsmittel des mit dem neuen "Sinn"-Horizont gesetzten bedeutungsgefüges der Form des Evangeliums dienen lässt und so auch den sprachlichen Zusammenhang des "Materials" (Sitz im Leben) verändert' (Güttgemanns 1971b: 257).

'n Mens kan in die lig van die feit wat Güttgemanns en ander stel, kwalik anders as om in te stem dat die gelykenisse, soos ook die ander tradisie-eenhede, in die eerste plek gelees en verstaan moet word in terme van die teksteoretiese en semantiese funksie wat hulle binne hulle nuwe raamwerk vervul. Dit is immers die raamwerk waarin ons hulle op skrif voor ons het, en elke poging om 'n voor-literêre konteks of raamwerk te rekonstrueer, is basies hipoteties van aard. Hoe waar dit egter ook al mag wees, is die saak tog nie so eenvoudig as wat dit lyk nie. Dit is naamlik uit die evangelies reeds duidelik dat vanweë redaksionele of outeursaktiwiteite daar dikwels verskillende raamwerke vir dieselfde tradisiemateriaal tot stand gekom het, met bepaalde semantiese implikasies. As voorbeeld kan hier verwys word na die vergelyking (similititude) van die verlore skaap by onderskeidelik Lukas 
(15: 3-6) en Matteus (18: 12-13). Volgens Lukas 15: 1, 2 het Jesus met hierdie vergelyking geantwoord op die kritiek van die Fariseërs en Skrifgeleerdes dat Hy met sondaars omgaan. Hierteenoor wil Matteus 18: 10, 14 die lesers klaarblyklik laat verstaan dat hulle nie die geringes in die gemeente moet minag en verstoot nie. Ons kan natuurlik antwoord dat albei die aanwendings van die vergelyking nie net moontlik is nie, maar ook volkome legitiem omdat die vergelyking hom vir meervoudige aanwending leen.

\section{IS DIE NUWE GESTALT DIE FINALE WOORD?}

Dit bring ons by ' $n$ belangrike vraag: Moet ons ondanks die feit dat die gelykenisse 'oop' en vir meervoudige aanwending bruikbaar was, aanvaar dat hulle skriftelike fiksering hierdie moontlikheid laat stol het en dat die outeur/vertellers van die evangelies inderdaad die laaste woord oor hulle betekenis gespreek het? Sou dit derhalwe illegitiem wees om òf na ' $n$ voor-literêre ò na 'n na-literêre moontlikheid van die verstaan van 'n gelykenis te vra? Interessant genoeg maak Güttgemanns self, in aansluiting by Koch (1974: 44-45), die volgende opmerking:

'Naturlich ist daneben ( $\mathrm{nl}$ die opname in die nuwe Gestalt en die gevolglike verandering van Sitz) auch eine weitere Verwendung der Bestandteile als Einzelgut denkbar, so dass der alte "Sitz im Leben" nicht einfach ausgerottet ist. Man kann auch mit der Trägheit der Gattungen rechnen, ihrere Neigung, über das Verschwinden des Sitzes im Leben hinaus in Übung zu bleiben, so dass nicht in jedem Fall von einer benutzten Gattung auf das gleichzeitige Bestehen des dazugehörigen Sitzes im Leben geschlossen werden darf' (1971b: 87).

Soos uit hierdie opmerking van Güttgemanns duidelik blyk, kan aanvaar word dat ' $n$ bepaalde vorm (Gattung) naas sy opname in ' $n$ nuwe Gestalt, nog in sy vorige Sitz kan bly voortleef en dat hy ook sonder ' $n$ bepaalde Sitz, bloot as vorm kan voortleef. Dit beteken eenvoudig dat die skriftelike raamwerk en aanwending van die gelykenisse in die evangelies, wat die vroegste kerk betref, nie die enigste was nie, maar slegs 'n deel van die totale leefruimte van die tradisiemateriaal, en so van die gelykenisse. Nou moet ons onmiddellik hierby sê dat die eis wat gestel word dat wanneer ons met die makro-teks werk, die gelykenisse steeds in die lig dáárvan geïterpreteer moet word, ten volle gehandhaaf moet bly. Die sinkroniese benadering tot die saak staan by die lees van die evangelies as outonome tekste dus voorop. Al is die skriftelike konteks derhalwe streng genome ' $n$ afgeleide en se- 
kondêre vorm van die situasie, bly dit vir die eksegese die primêre aanknopingspunt (Sellin 1982: 416). Wat wel betoog moet word, is dat daar ook' $n$ ander kant van die saak is. Hierdie ander kant van die saak word myns insiens raak beskryf deur Via (1974: 178-179).

Via (1974: 178-179) gee toe dat die gelykenisse, wanneer hulle in die evangelies opgeneem word, 'vehicles for the expression of the whole kerygmatic meaning of the Gospels' word. Maar dan voeg hy hieraan toe:

'We must, however raise the question whether the evangelists actually are able to carry out their intention to make the parables subsidiary to the structure of the Gospels. It is my judgement that the parables - because they are aesthetic objects, because of their organic interlocking of form-and-content - resist the effort to assimilate them to the form of the Gospels in a way that the other materials used by the evangelists do not' (egter ook nog ander vorme soos sommige wonderberigte en apoftegmas; vgl ook Wilder 1976: 82 - GMMP).

Ook die volgende paar opmerkings van Wilder is ter sake: 'That parts of a Gospel, including the parables, belong together and illuminate each other and the whole is not in question. But the parts and the whole are not a self-enclosed sequence separate from the actualities which it recites or from their antecedents. The "story-world" is one face of a determining event-world' (1982: 30; beklemtoning deur my). 'The point is that "what is written", in the case of texts like these, is profoundly referential and does not belong only to some detached "storyworld". Those who treat them otherwise, in the interest of either literary or structuralist criticism, impoverish their communation. Thus we are left with Gospels or parables deprived of their dynamics and orientation' (1982: 31). Soos Wilder self laat blyk, staan hy nie negatief teenoor 'n 'literêre' lees van die evangelies en die gelykenisse nie. Hy meen egter dat wat hy noem die konflik tussen die literêr-linguistiese en historiese benaderings, opgelos moet word deur ' $n$ beter verstaan van beide. 'The former leaves us with free-floating texts which move towards gratuity and fantasy. The latter evacuate the recitals of their full import in the quest for facts and thematics. What is called for is a literary method which takes better account of the relation of language to reality, understanding reality, however, also in its historical dimension' (1982: 32).

Daar moet op gewys word dat in meer resente navorsing wat op die gelykenisse gedoen is deur mense wat steeds die oorspronklike situasie probeer rekonstrueer, ook aandag gegee is aan die evangeliekontekste 
waarin die gelykenisse hulle tans bevind (so bv Weder 1978; Stein 1981). Hoewel daar in gevalle soos hierdie wegbeweeg is van 'n te eensydige oorbeklemtoning van die vraag na die oorspronklike situasie, word daar tog nog van die veronderstelling uitgegaan dat die oorspronklike vorm èn historiese situasie gerekonstrueer kan word. Het ons ooit die hoop om die oorspronklike historiese situasie vas te stel? Sellin verwoord die standpunt van baie ander wanneer hy stel: 'Die konkrete historische Situation der Entstehung eines einzelnen Gleichnisses ist ... prinzipiell unzugänglich' (1982: 405).

\section{IS HISTORIESE REKONSTRUKSIE MOONTLIK?}

Moet of kan daar met hierdie stelling van Sellin saamgestem word? Daar is reeds hierbo daarop gewys dat waterdigte kriteria vir die vasstelling van die oorspronklike Jesuswoorde nie werklik bestaan nie of minstens debatteerbaar is. Die probleem word nog groter wanneer gevra word na die oorspronklike historiese situasie. Hoe stel ons dit histories vas? Ons het alleen die situasies wat deur die evangeliste geskilder word en in baie gevalle word daar selfs nie in die evangelies 'n situasie aangegee nie. Ons het dus nie alleen met die prinsipiële vraag te doen nie, maar ook met die vraag na die moontlikheid van so 'n rekonstruksie (vgl Via 1974: 21; Scott 1981: 24; Steiner \& Weymann 1979: 21; Sider 1983). In die lig van al die probleme rondom die saak, lyk die gevolgtrekking onvermydelik dat dit nie meer moontlik is om so ' $n$ rekonstruksie uit te voer nie. Dit beteken natuurlik hoegenaamd nie dat die historiese rondom Jesus en sy boodskap hiermee totaal uit die gesigsveld verdwyn nie. Al wat hiermee gesê word, is dat die rekonstruering of omlyning van spesifieke historiese situasies nie meer uit die tekste tot ons beskikking moontlik is nie.

Maar laat dit ons dan weer slegs met die skriftelike konteks wat ons voor ons het? Die opmerkings van Güttgemanns en Via waarna reeds verwys is en wat ' $n$ weerspieëling is van die ander sy van die saak, noop ' $n$ mens om nie hiermee te volstaan nie. Heelwat van die elemente van die evangeliese tradisie, soos hulle in hulle huidige konteks geïnkorporeer is, wek by 'n mens die indruk dat hulle nie volkome vrygemaak is van hulle vorige kontekste of strukture nie. '... the uses to which they may be put are restricted by their nature and signification in previous structures' (McKnight 1978: 247). Dit geld ook veral van die gelykenisse wat in 'n sekere sin met die evangelies wedywer om die aandag van die leser (Via 1974: 179). 


\section{HOE SOU ONS TRADISIE EN REDAKSIE TOG SINVOL KON SKEI?}

Behalwe in ekstreme gevalle word daar vandag bykans algemeen aanvaar dat beide die sinkroniese en diakroniese eksegetiese metodes bestaansreg het, en in so ' $n$ mate dat albei aanvullend tot mekaar gebruik kan word. Hoewel die sinkroniese dus voorop staan, word aanvaar dat die diakroniese ook sy bydrae kan en moet lewer vir die interpretasie van die Bybeltekste. Hoe die twee aanvullend tot mekaar gebruik moet word, is egter nie altyd duidelik nie. (Frankemölle 1982 probeer dit klaarblyklik met sy kommunikatiewe model van pragmatiese eksegese doen.) Feit is egter dat ons hier met twee wesenlik verskillende teksteorieë te make het wat nie met mekaar vermeng mag word nie. Dat die diakroniese vraagstelling ook altyd vir die sinkroniese van waarde sal wees, kan seker ook nie beweer word nie. Nietemin lyk dit legitiem en moontlik om in verband met die gelykenisse as tradisievorme tog vanuit die diakroniese invalshoek ' $n$ bepaalde bydrae te maak. Die bydrae wat gemaak word, sal waarskynlik geen verandering aan die sinkroniese lees van die evangelies teweegbring nie, maar dit kan wel van betekenis wees vir die eksistensiële ontmoeting van die leser met hierdie vorme. Dit kan vir hom naas die wêreld wat die vorme in hulle huidige konteks vir hom geskep het, nuwe geloofshorisonne open en hom so tot 'n beter verstaan bring van sy verhouding met Hom wat deur middel van hierdie teks met Hom in ontmoeting tree. ' ... the tradition, the historical elements embedded in forms, impinge upon man and have signification' (McKnight 1978: 248).

Maar as dit nie meer vir ons moontlik is om die voor-literêre konteks(te) van die gelykenisse met sekerheid te rekonstrueer nie, watter moontlikheid bly daar dan tog om hulle 'ander' stem(me) ook te hoor? Die beste oplossing tot dusver is myns insiens deur Via aangebied (aangeprys deur Güttgemanns 1971a: 147-148, 229). Via beskou die gelykenisse, of in elk geval die meerderheid van hulle, as selfstandige estetiese objekte (so ook TeSelle 1975: 79) wat nie na iets buite hulle verwys nie en ook nie hulle betekenis van buite ontvang nie. "The peculiar function of language used aesthetically is that through its centripetal interlocking of content into form it grasps the attention of the beholder as a total psychosomatic unity - including conscious and unconscious aspects - in an intransitive or non-referential way' (Via 1974: 79).

Die imphkasie hiervan is dat die eenheid van die gelykenisse nie 
soos in die geval van 'n streng historiese benadering versteur kan word en dat hulle betekenis nie uitgeput kan word deur hulle aan een spesifieke situasie te bind nie. Hiermee hang saam dat hulle betekenis ook nie vereng of verskraal kan word tot een punt van vergelyking en dat die ander elemente oor die hoof gesien kan word of dat hulle onbewustelik selfs geallegoriseer kan word nie. So sou hulle inderdaad tot stilstand gebring word en alleen nog iets te sê hê vir 'n vergange situasie en nie nuwe verstaan en betekenis in nuwe lewensituasies open of skep nie. 'A metaphor is neither reducible to one point nor is its "meaning" foreclosed in some historical moment: it is rather generative of new meanings in the plural' (TeSelle 1975: 72; vgl ook Steiner \& Weymann 1979: 21-22; Wittig 1976: 336). Die implikasie in teenstelling met die streng literêre benadering, is dat hoewel die gelykenisse 'n bydrae maak tot die betekenis van die makro-teks en ook van die betekenis van die makro-teks in hulle opneem, hulle as outonome estetiese objekte hulleself in 'n sekere sin distansieer van die primêre teks.

'The parable inserts a narrative into a narrative, a text into its context. This is a closed series of events which from the narative point of view is not in continuity with the story. Personages appear without any syntactic relation to the personages in the primary narrative. Actions are produced which are unconnected to preceding actions. In this regard we can say that the parables are distanciated from the primary narrative. They lay down the conditions for a hermeneutic by exposing themselves as a "text", (Entrevernes Group 1978: 236).

Dit is hierdie selfstandigheid van die gelykenis as vertelling met 'n eie vertelde wêreld, wat maak dat hy homself as outonome teks met eie betekenisgenererende potensiaal handhaaf, selfs wanneer hy in ' $n$ makro-teks gebruik word om in terme van die intensie van die nuwe Gestalt te funksioneer. Die feit dat 'n gelykenis as estetiese objek outonoom is en dat sy betekenis sentripetaal, nie-referensieel en intransitief is, beteken egter nie dat daar geen verwysing na die wêreld buite die teks is nie. 'The various elements are given a new context and frame of reference, to be sure, but in themselves they still relate in some way to what is already known. Otherwise there would be no communication (Via 1974: 79). In so 'n literêre estetiese objek word die aandag gefokus op die werk self, terwyl die leser daarvan bewus word van ' $n$ verwysing in ondergeskikte sin (subsidiarily) na die wêreld buite die teks (Via 1974: 86-87). Om die saak te illustreer, sluit Via hom aan by Krieger (1964: $30-1,33-6,59-65)$ se beskouing oor die relasie tussen ' $n$ literêre 
werk en die werklike wêreld, sonder dat die werk daarmee sy outonomie prysgee. Wanneer 'n literêre werk na behore funksioneer, staan dit agtereenvolgens as venster, spieël, venster in 'n relasie tot die wêreld. Eerstens is dit ' $n$ stel vensters waardeur ons die bekende wêreld deur verwysinge in die teks sien. Dan verander die vensters in spieëls wat na binne op mekaar reflekteer. Binne hierdie gereflekteerde ruimte word die bekende en dit wat tot dusver nog nie waargeneem is nie, georganiseer in ' $n$ nuwe patroon van verbindinge, sodat daar in hierdie patroon 'n implisiete eksistensiële verstaan aanwesig is. Uiteindelik verander die spieëls weer in vensters wat vir ons 'n nuwe visie op die wêreld gee.

Dit is duidelik dat Via nie die gelykenisse tot onhistoriese entiteite maak soos sommige (o a Frankemölle 1982: 72) meen nie. Hy beweer dus nie dat die gelykenisse hoegenaamd nie na die situasie van die aardse Jesus verwys nie. "The parables do point in a subsidiary way to Jesus' historical situation, and interpretation must also take this into account. They are windows to Jesus' ministry in both ways ...' (Via 1974: 93). Die wêreld waarvan hulle ons 'n nuwe visie gee, is die wêreld waarheen Jesus gekom het, en hulle onlosmaaklike verbintenis met Jesus se heilswerk gee aan hulle 'n normatiewe waarde vir die teoloog. In 'n sekere mate is dit deur die gelykenisse dat die Christendom Jesus sien soos hy Hom sien.

Via maak ook nie die gelykenisse los van die evangelies nie, maar omdat hulle eie karakters het en hulle eie outonome wêreld ' ... they cannot become merely subsidiary to the structure of the Gospels but rather contend inevitably with the latter for the focal attention of the reader' (Via 1974: 179). So bied die gelykenisse 'n leidraad vir die betekenis van die evangelies en lei hulle, in hulle huidige posisie, 'n deel van hulle betekenis van die evangelies af.

'n Belangrike vraag bly nog oor: Volgens watter kriteria besluit Via oor waar die grense van die gelykenis lê? Of om dit in die terme van ons ondersoek te stel, hoe skei hy tussen tradisie en redaksie? Via volg in sy interpretasie van die gelykenisse drie stappe waarvan slegs die eerste ons met betrekking tot ons onderwerp interesseer. Hy noem hierdie stap die histories-literêre kritiek ('historico-literary criticism'). Dit blyk dan dat hy hom vir die doeleindes van die afbakening van die gelykenis, laat lei deur die plot van die vertelling of die tema daarvan. Albei is in ' $n$ vertelling aanwesig en staan in ' $n$ bepaalde relasie tot mekaar. In sommige vertellings is plot meer prominent en in ander weer tema (Via 1974: $100 \mathrm{v}$ ). Die vorm en inhoud as organiese eenheid 
dien dus as belangrike kriterium vir die identifisering van die gelykenis as estetiese objek. Hierbenewens gaan Via egter ook redaksie-krities te werk en suiwer uit wat hy as toevoegings by of kommentaar op 'n gelykenis beskou. So oordeel hy byvoorbeeld ten opsigte van die gelykenis van die onregverdige bestuurder (Luk 16: 1-3) dat 16:9, $10-12,13$ oorspronklik nie met die gelykenis verbind was nie en ook nie met mekaar nie, maar deur Lukas toegevoeg is op die basis van die trefwoord 'mammon'. Verder beskou hy vers 8a as deel van die gelykenis en kurios as verwysend na die eienaar in die vertelling (Via 1974: 156).

\section{GEVOLGTREKKING}

Dat ons by die lees van die evangelies as outonome literêre Gestalten met eie perspektiewe, die gelykenisse moet interpreteer in terme van hulle funksie in en bydrae tot die betekenis van die makro-teks, staan buite diskussie. Dit beteken dat ons nie, wanneer ons 'n evangelie lees, daarmee saam ook alle veronderstelde voorafgaande tradisielae kan lees, nie. 'Der Leser kann nicht in verschiedenen Textschichten lesen, und auch kein einziger Text will so gelesen werden, auch nicht, wenn er tatsächlich aus mehreren Schichten zusammen-gewachsen ist' (so tereg Van lersel, aangehaal deur Frankemölle 1982: 63).

Die gelykenisse vertoon egter 'n besondere karakter wat hulle ten spyte van die feit dat hulle in die nuwe Gestalten opgeneem is, laat uitstaan. Hulle dring hulleself eenvoudig aan 'n mens op as tekste met minstens ' $n$ bepaalde selfstandigheid en outonomie. Hulle onderskei hulleself deur middel van hulle eie karakters, vertelde wêreld en dikwels nuwe en verrassende visie wat hulle op die werklikheid open. Hulle ding beslis met die evangelies mee om die aandag van die leser. Dit is veral te bespeur in die gevalle waar die onmiddellike konteks waarin sekere gelykenisse geplaas is, duidelik in skrille kontras staan met die betekenismoontlikhede van gelykenisse. Hiermee word natuurlik nie ontken dat daar wel verskeie gevalle is waar die aanwending wat die gelykenis gevind het, heeltemal toepaslik blyk te wees nie. Die verskillende wyses waarop hulle in die evangelies aangewend is, dui egter op hulle oopheid en betekenisgenererende dinamiek. Dit dui ook daarop dat hulle lewende tekste (vertellings) is wat nie hermeneuties aan slegs een raamwerk of situasie geknoop en daarmee vir ander situasies onbruikbaar gemaak kan word nie. Hulle rig elkeen 'n eie uitnodiging aan die leser om deel te word van die nuwe wêreld wat 
hulle vertellend vir hom skep. Hulle roep die leser op tot 'n eksistensiële selfverstaan en ervaring in die lig van die Christusgebeure. Hulle staan dus beslis nie los van die werklikheid wat deur die Christusgebeure tot stand gebring is nie. Om egter die spesifieke situasies te bepaal waarop hulle onderskeidelik in die loop van hierdie gebeure betrekking gehad het, is nie meer moontlik nie. Om in die lig van hierdie feit van die oorspronklike of ware of eintlike betekenis van 'n gelykenis te praat, lyk nie alleen nie moontlik nie, maar prinsipieel ook onaanvaarbaar.

Hierby moet egter gesê word dat willekeur by die interpretasie en toepassing van hierdie vertellings nie toelaatbaar is nie en deur die poëtiek daarvan uitgesluit is. Dit is uitgesluit juis omdat 'n gelykenis vanweë sy eie struktuur bepaalde riglyne vir interpretasie bevat en beperkinge op die leser lê. Hoewel hulle dus 'oop' is vir meervoudige verstaan, is hulle nie oneindig oop nie. Daar kan nie op absurde wyse met hulle omgegaan word nie en dit is alleen in die relasie tussen teks en leser as ' $n$ hermeneutiese sirkel, waarin hulle aan die woord kom. In hierdie hermeneutiese sirkel sal hulle verkeerde vrae korrigeer en die leser help om nie aan hulle vrae te stel waarop hulle nie antwoorde het nie. Hulle bly dus die leser vóór deur die wyse waarop hulle hom aanspreek en het steeds die laaste woord oor hulle betekenismoontlikhede.

Die voordeel daaraan verbonde om die gelykenisse te lees en te verstaan in die verband waarin ons hulle tans konkreet in hulle skriftelike konteks voor ons het, bly natuurlik steeds dat daar nie na 'n hipotetiese konteks gesoek hoef te word of gepoog moet word om tussen tradisie en redaksie te skei nie. 'n Mens moet erken dat ten opsigte van sekere gelykenisse, die pogings wat aangewend is om die gelykenisse te isoleer of ' $n$ interpretasiekonteks daaroor te vind, nie baie bemoedigend is nie. Dit blyk dat argumente en kriteria wat deur die een na vore gebring word, deur die ander weer op ander gronde verwerp word. Subjektiwiteit speel 'n rol. Maar subjektiwiteit sal nooit uitgeskakel kan word nie. Daar kom 'n punt waar 'n mens 'n keuse moet maak, en dan speel subjektiwiteit beslis ' $n$ rol.

Daar is natuurlik ook die vraag of ' $n$ mens eers na ' $n$ konteks moet soek of een moet veronderstel voordat die gelykenis jou sal kan of mag aanspreek. Gebeur dit nie in werklikheid so dat 'n teks self die konteks skep waarbinne die leser dit verstaan nie? Die ervaring van die leser mag juis wees en is dit waarskynlik altyd dat die konteks waarbinne hy 'n teks begin lees, deur die teks self verander word of deur 'n totaal 
ander konteks vervang word namate hy die teks ervaar as 'n krag wat nuwe verstaanshorisone skep.

\section{DIE VERHOUDING TRADISIE-REDAKSIE EN DIE 'GELYKENIS' VAN DIE BARMHARTIGE SAMARITAAN (LUK 10)}

Die wyse waarop die kwessie van die skeiding van tradisie en redaksie tot dusver met betrekking tot die vertelling van die Barmhartige Samaritaan gehanteer is, mag aan die een kant gesien word as juis die bewys van die ontoelaatbaarheid van die skeiding van tradisie en redaksie, maar aan die ander kant kan dit ook bewys lewer van die nuwe verstaansmoontlikhede wat so ' $n$ prosedure open. Ons vind naamlik in hoofsaak die volgende afbakenings vir die teks waarmee gewerk word: vss 25-37 (Entrevernes Group 1978: 13; Linnemann 1961: 57; Stein 1981: 74); vss 29-37 (Boucher 1981: $118 \mathrm{v}$ ); vss 30-37 (Bultmann 1967: 64; Wilder 1971: 60); vss 30-35 (Scott 1981: 25; Jüngel 1967: 170); vss 30b-35 (Patte 1974: 14; Funk 1974: 77; Crossan 1974: 193).

Soos die vertelling van die Samaritaan in sy huidige konteks in die evangelie aangewend is, is dit duidelik dat die funksie daarvan is om naasteskap mee te illustreer. Dit is dan ook op grond hiervan dat die vertelling deur die meerderheid as ' $n$ voorbeeldvertelling geklassifiseer word en nie as ' $n$ gelykenis nie. Die vraag is egter of dit ooit as 'n voorbeeldvertelling bedoel was of slegs so geïnterpreteer kan word. Baie eksegete voel in die konteks 'n spanning aan tussen enersyds die vraag: wie is my naaste? (vs 29) en andersyds die vraag in vers 36 oor wie die man langs die pad se naaste was, terwyl ander dit nie as 'n spanning ervaar nie. Natuurlik is dit volkome aanvaarbaar dat die konteks by Lukas beide kante van naasteskap onder woorde wou bring.

Ons kan natuurlik nie met stelligheid beweer dat die outeur van Lukas uitsluitlik verantwoordelik was vir die kontekstualisering van die vertelling nie. Dat die vertelling egter geïsoleerd ' $n$ betekenisvolle eenheid vorm, kan nie betwis word nie (Entrevernes Group 1978: 16). In so 'n geval sal dit ook nie meer as ' $n$ voorbeeldvertelling beskou kan word nie, maar as 'n gelykenis (vgl ook Crossan 1973: 65). Dit is inderdaad 'n vraag of die vertelling as 'n voorbeeld bedoel was. Funk byvoorbeeld betwyfel dit sterk, soos blyk uit sy stelling '... the parable does not invite the hearer to view it as an example of what it means to be a neighbour' (1974: 76). Lees ons dit dan teen die agtergrond van die Jesusgebeure of meer bepaald die koninkryk van God, open dit nuwe 
vergesigte. In so 'n geval dien dit dan nie meer as 'n blote voorbeeld vir optrede nie, maar nooi dit die leser uit tot 'n nuwe ervaring van die werklikheid of tot die ervaring van 'n nuwe, ander werklikheid, die koninkryk van God, waarom alles per slot van rekening gaan. In so 'n geval kan die gelykenis vir die leser die geleentheid skep om onder andere tot die volgende moontlikhede van eksistensiële verstaan en bestaan te kom:

- Dit kan hom oorreed om die rol van die Samaritaan te vervul en sodoende te handel en te lewe soos dit hoort in die koninkryk van God, naamlik in liefde sonder voorwaarde, sonder diskriminasie en sonder reserwe.

- Dit kan hom wakker skok by die besef dat wat hy tradisioneel en in die werklike wêreld waarin hy hom bevind, as goed beskou, sleg kan wees en wat hy as sleg beskou, goed kan wees, en so kan dit hom tot radikale herwaardering van sy waardes, voorkeure en vooroordele bring in die lig van wat in die koninkryk van God as maatstaf geld.

- Dit kan deur die onsêbare te sê, naamlik goeie-Samaritaan, hom ook tot ' $n$ herwaardering bring met betrekking tot wat hy tradisioneel as onsêbaar beskou het, en hom dienooreenkomstig laat handel.

- Dit kan hom selfs die posisie van 'the man in the ditch' (Funk 1974: 79) laat inneem, sodat hy vanuit hierdie posisie kan ervaar wat die onuitspreeklike barmhartigheid en genade van God werklik inhou.

Die gelykenis mag selfs nog meer as dit vir die leser tot ' $n$ eksistensiële gebeurtenis laat word, nie as 'n sedeles nie, maar as 'n ervaring van ' $n$ nuwe bestaansmoontlikheid waarin dit wat hy in werklikheid is, vervang word met wat hy in waarheid is: die nuwe mens in Christus.

\section{Literatuurverwysings}

BOUCHER, MI 1981. The parables. Wilmington: Michael Glazier, Inc.

BULTMANN, R 1967. Die Geschichte der synoptischen Tradition. 7. Auflage. Göttingen: Vandenhoeck.

CROSSAN, JD 1973. In parables: The challenge of the historical Jesus. New York: Harper \& Row.

CROSSAN, JD 1974. Structuralist analysis and the parables of Jesus. Semeia 1, 192-221. DODD, $\mathrm{CH}$ 1965. The parables of the kingdom. 2nd ed. Digswell Place: Nisbet.

FRANKEMÖLLE, H 1982. Kommunikatives Handeln in Gleichnisse Jesu: Historischkritische und pragmatische Exegese. Eine kritische Sichtung. NTS 28, 61-90.

FUCHS, E 1970. Hermeneutik. 4. Auflage. Tübingen: Mohr.

FUNK, RW 1966. Language, hermeneutic and the word of God. New York: Harper \& Row.

FUNK, RW 1974. The Good Samaritan as metaphor. Semeia. 2, 74-81. 
GÜTTGEMANNS, E 1971a. Studia Linguistica Neotestamentica. München: Chr Kaiser.

GÜTTGEMANNS, E 1971b. Offene Fragen zur Formgeschichte des Evangeliums. München: Kaiser.

JEREMIAS, J 1962. Die Gleichisse Jesu. Göttingen: Vandenhoeck.

JEREMIAS, J 1973. Neutestamentliche Theologie: Erster Teil. Die Verkündigung Jesu. Gütersloh: Gerd Mohn.

JÜNGEL, E 1967. Paulus und lesus. 3. Auflage. Tübingen: Mohr.

$\mathrm{KOCH}, \mathrm{K}$ 1974. Was ist Formgeschichte. 3. Auflage. Neukirchen-Vluyn: Neukirchener Verlag.

KRIEGER, M 1967. A window to criticism. Princeton: Princeton University Press.

LINNEMANN, E 1961. Die Gleichnisse Jesu: Einführung und Auslegung. Göttingen: Vandenhoeck.

McKNIGHT, EV 1978. Meaning in texts: The historical shaping of a narrative hermeneutics. Philadelphia: Fortress.

PATTE, D 1974. An analysis of narrative structure and the Good Samaritan. Semeia 2, $1-26$.

PERRIN, N 1967. Rediscovering the teaching of Jesus. London: SCM.

SCOTT, BB 1981. Jesus, symbol-maker for the kingdom. Philadelphia: Fortress.

SELLIN, G 1982. Allegorie und "Gleichnis": Zur Formenlehre der synoptischen Gleichnisse, in Harnisch, W (Hrsg). Die neutestamentliche Gleichnisforschung im Horizont von Hermeneutik und Literaturwissenschaft. Darmstadt: Wissenschafliche Buchgesellschaft.

SIDER, JW 1983. Rediscovering the parables: The logic of the Jeremias tradition. JBL 102, 61-83.

SNODGRAS, K 1983. The parable of the wicked tenants. Tübingen: Mohr.

STEIN, RH 1981. An introduction to the parables of lesus. Philadelphia: Westminster.

STEINER, A \& WEYMANN, V (Hrsg) 1979. Gleichnisse lesu. Basel: Friedrich Reinhardt.

TeSELLE, SM 1975. Speaking in parables. Philadelphia: Fortress.

THE ENTREVERNES GROUP 1978. Signs and parables: Semiotics and Gospel texts. Pittsburgh: Pickwick.

VAN AARDE, AG 1982. God met ons: Dié ideologiese perspektief van die Matteusevangelie. DD-proefskrif, Universiteit van Pretoria.

VAN AARDE, AG [1982]. Die vertellersperspektief-analise: 'n Literatuurteoretiese benadering in die eksegese van die evangelies. Hervormde Teologiese Studies 38, 58-82.

VIA, DO 1984. The parables: Their literary and existential dimension. Philadelphia: Fortress.

VORSTER, WS 1982. Formgeschichte en Redaktionsgeschichte, in Klijn, AFJ (red), Inleiding tot de studie van het Nieuwe Testament. Kampen: Kok.

WEDER, H 1978. Die Gleichnisse Jesu als Metaphern. Göttingen: Vandenhoeck.

WILDER, AN 1971. Early christian rhetoric: The language of the gospel. Cambridge: Harvard University Press.

WILDER, AN 1976. Jesus' parables and the war of myths. London: SPCK.

WITTIG, S 1976. Meaning and modes in signification: Toward a semiotic of the parable, in Patte, D (ed), Semiology and the parables: An exploration of the possibilities offered by structuralism for exegesis. Pittsburgh: Pickwick, 319-347. 